\title{
DO CELL GROUP INDEPENDENT ACTIVITIES IMPACT STUDENTS' SCORE ACHIEVEMENT?
}

\author{
Melania Wiannastiti \\ English Department, Faculty of Humanities, Bina Nusantara University \\ Jl. Kemanggisan Ilir III no 45, Kemanggisan, Palmerah, Jakarta barat 11480 \\ mwiannastiti@binus.edu ; Senthita@yahoo.com
}

\begin{abstract}
There are many methods offered to teach in a university level. In teaching English Entrant, one course of general English courses at Binus University, a lecturer needs to choose an appropriate method. One appropriate method used is cooperative learning one. In this method, students in a class are divided into groups called cell group. In the cell group, they needed to do some activities independently. Based on the above reason, this paper aimed to find out whether the cell group independent activities impact the students' score achievement in reading and listening. The data for the paper was the students' scores of listening and reading they gained in mid semester test, final test English Entrant and the weekly reports of students' cell activities. The method used to analyze the data was percentage number to compare the scores and cell group activities for both listening and reading. The result shows that there was a significant higher achievement of the students in both listening and reading either the number of cell group activities 1-3 or 4-6 times of activities. It could be concluded that the cell group activities gave good impact in supporting students to achieve high score in reading or listening.
\end{abstract}

Keywords: Cooperative learning, cell group method, listening and reading scores, weekly report

\begin{abstract}
ABSTRAK
Ada banyak metode yang ditawarkan untuk mengajar di tingkat universitas. Dalam mengajar peserta bahasa Inggris, salah satu program kursus bahasa Inggris umum di Binus University, dosen berkebutuhan memilih metode yang tepat. Salah satu metode yang tepat digunakan adalah salah satu pembelajaran kooperatif. Dalam metode ini, siswa dalam satu kelas dibagi menjadi kelompok-kelompok yang disebut kelompok sel. Dalam kelompok sel, mereka melakukan beberapa kegiatan secara mandiri. Berdasarkan alasan tersebut, makalah ini bertujuan untuk mengetahui apakah kegiatan kelompok sel independen memengaruhi prestasi skor siswa dalam membaca dan mendengarkan. Data untuk makalah ini adalah skor mendengarkan dan membaca yang mereka peroleh dalam tes mid semester, tes akhir peserta bahasa Inggris, dan laporan mingguan dari aktivitas sel siswa. Metode yang digunakan untuk menganalisis data adalah persentase untuk membandingkan nilai dan kegiatan kelompok sel, baik untuk mendengarkan dan membaca. Hasil penelitian menunjukkan bahwa ada prestasi signifikan yang lebih tinggi dari siswa dalam mendengarkan dan membaca, baik jumlah kegiatan kelompok sel 1-3 maupun 4-6 kali kegiatan. Dari sini dapat disimpulkan bahwa kegiatan kelompok sel memberikan dampak yang baik dalam mendukung siswa untuk mencapai skor tinggi dalam membaca atau mendengarkan.
\end{abstract}

Kata kunci: Pembelajaran kooperatif, metode kelompok sel, skor mendengarkan dan membaca, laporan mingguan 


\section{INTRODUCTION}

Many lecturers become more creative in choosing and applying methods in their classroom especially if the number of students is more than forty. Moreover, if in this big class a teacher has to teach English in which some skills such as listening, speaking, reading, writing and grammar need to be taught at once. It is really not easy to handle the students as well as to transfer the material and knowledge at the same time. Besides transferring the knowledge, the progress of the students becomes a matter. Since there are too many students, it is not easy to see the progress of each student in a class. Possibly, a teacher or a lecture can only handle the progress of the students for maximum twenty persons. Moreover, some lecturers have difficulties in controlling the students' activities in the classroom.

It is believe that most lecturers prefer to teach small classes to the big one as it is said by Richard and Renandya (2002) "Most of teachers find themselves working with a class of fifty students or more and to make the matters worse, these students often exhibit a wide variety of abilities". The variety forces lecturers to design or apply methods of teaching and activities which cover all abilities targeted. One method used by the writer in teaching English Entrant was cell group method which was supported by Binusmaya and Binusmaya Forum, in which students were able to communicate either with the lecturers or with their classmate especially in discussing the material and assignment.

Since the target of the students' achievement in for English Entrant is IBT TOEFL Test, while the number of students varies from 40 - 70 students, the writer applied one cell group discussion in which the activities were done by students in cell group outside of the classroom. Based on the reason, this paper is mainly to find out whether the number of activities the students did outside the classroom give any impacts their achievement especially in reading and listening scores and to explain the activities the students did from the weekly report they made.

\section{Theoretical Framework}

This paper is grounded on a method suggested by Hammer which is famous as the Communicative Approach. It is a guiding principle to train students to use language form appropriately in variety of context and for a variety of purposes (Harmer: 2001). In this context, students are asked to be able to communicate to others using the targeted language. Both of the method can be combined to teach big classes. However, these methods do not cover all the skills in limited time. Teachers have no enough time checking students progress one by one if the students are more than fifty.

One other method suggested by Jacobs and Hall (2002) which is used mostly in this paper is called Cooperative Learning. This method does not only mean putting students in group and have something to do but it is a tool which teachers use to encourage mutual helpfulness in the group and the active participation of all members (2002:52). This method also enables teachers to give some tasks to do in the group in which each of the member in a group help one another to develop their English skills better as it can be said as a TEAM which is derived from Together Each Achieve More. By using this idea, students are groups in four or five called Cell Group. They are hoped to do some activities together in the cell group and share ideas as well as practicing their English skills. Students are situated in which s/he as a member of the group get the opportunity to develop him/herself in the group and helps others to develop themselves too.

A good method needs a good support. One of the supports used in the method chosen to support the teaching learning of the language is the internet. This media will help teachers and students to reach the objectives of the teaching learning. According to $\mathrm{Li}$ and Hart stated in Richard 
and Renandya (2002) the internet possesses a number of features which particularly suited second language learners' growing proficiency in language. Therefore the internet enables teachers to find more variety in language teaching and supporting the method they choose.

One media of the Internet used in this paper is called BINUSMAYA. It is a website provided by the university for the lecturers and students to communicate. This website provides schedule, material for teaching, detail information and BINUSMAYA FORUM in which among students and lecturers can communicate with the active students in the lectures they teach in a certain semester. For students, BINUSMAYA provides all information about their study including the lectures they take in the active semester.



Picture 1 BINUSMAYA

BINUSMAYA FORUM a part of BINUSMAYA is the room provided where lecturers and students who take the same lectures either in the same class or parallel classes are able to communicate outside of the classroom. BINUSMAYA also provides rooms for lecturers and students to discuss some topics concerning with the lecturers they learn as well as uploading and downloading assignments. Picture 2 is BINUSMAYA FORUM

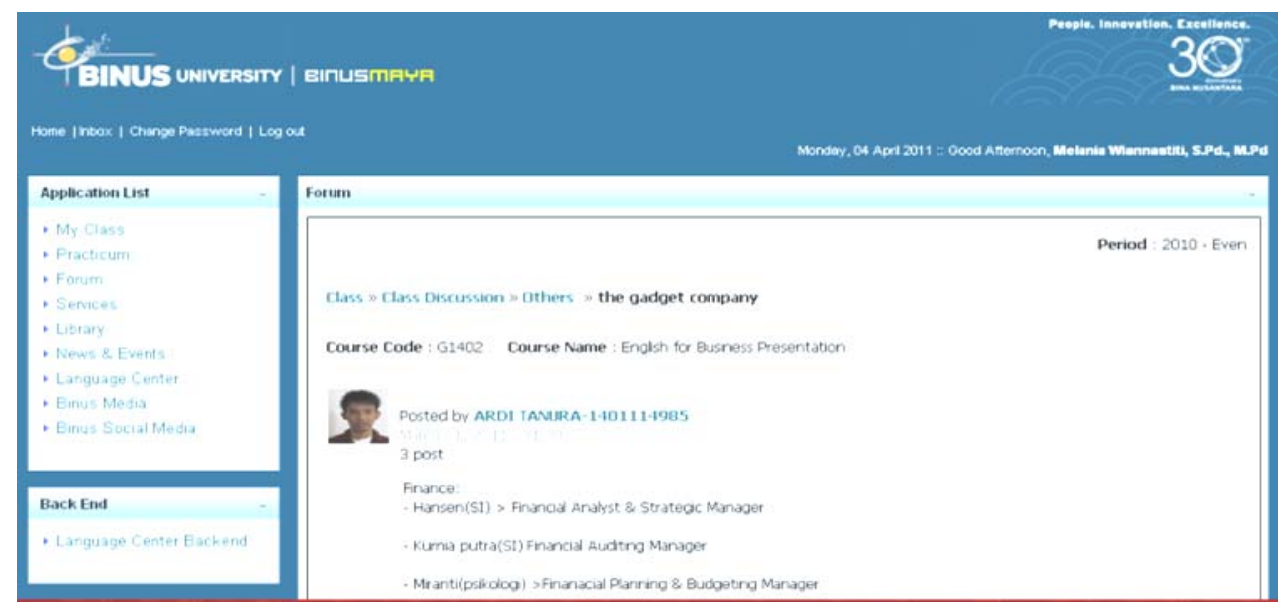

Picture 2 Binus Maya Forum 


\section{RESEARCH METHOD}

The object of this study is to find the effect of the number of cell group discussion toward their achievement of their listening and reading skills, therefore the data for this study are the mid-test result and the final test score and weekly report of each group in which they report their independent cell group activities per week.

The subject data of this paper is class 01PHJ who took entrant class in odd semester the academic year 2011 / 2012 which consisted of 60 students. The class was grouped into 12 cell groups, in which each consisted of 5 persons. The writer chose the group based on the attendance list. The reason was that they were new students who did not know one another, so there was no preference in grouping them. In grouped they were asked to work in cell group outside of the classroom. Each week for 7 weeks, they were asked to work independently for doing activities outside of the classroom to develop their listening, speaking, reading, and writing skills. Each week also they were asked to report what they did during a week. The writer did not limit the number of activities but stated the minimum activities i.e. one in a week.

The data then was analyzed by using percentage to show the impact of the students achievement in reading and writing in which the scores were taken from the test digitally. This score was valid since there was no preference of the lecture.

\section{RESULTS AND DISCUSSION}

\section{General English at Binus University}

As a compulsory lecture for undergraduate students at Binus University, General English is divided into three lectures; English Entrant, English In Focus and English Savvy. The target of them is the same level of English IBT TOEFL which equals to 500 score PBT TOEFL. Before new students enter the university, they have to join English pre test using PBT TOEFL test like. Their score determines in which level they have to join. Only the ones whose score are under 500 have to join English Entrant. The ones who get 500 or more score have to join the different programs called English Business Presentation. Therefore, the students are homogenous.

The number of students in English Entrant class is more than 50 per class and normally about 60 - 70 students. Limited time - 100 minutes - per session, 13 sessions and five skills to learn push a lecture to use a certain method to reach the learning outcomes. One method to offer is cooperative learning in which the number students in a class are divided into groups of five.

\section{The Method used in the English Entrant Classroom for 01PHJ Class}

Cooperative learning method, in which a class was divided into groups, put the students as the center of attention in learning process. In classroom, students are asked to make groups of five and it was called a cell group. Each cell group had a leader and four members. One advantage of creating the cell group was to make it easy to control their attendance in the classroom as student's attendance was one of the requirements to determine whether they were allowed to join the final examination or not.

Since the language skills to learn cover four skills; listening, reading, writing and speaking for business, cell groups had important role to develop the members to reach the learning outcomes. Each cell group was directed to multichannel learning with different activities of each skill. The learning 
activities for each group were cell group discussion, cell group review, cell group presentation and self access learning. Those activities were done in multi channel learning by using BINUS MAYA, BINUS MAYA FORUM, Self access learning laboratory and email. By using multi channel learning, each cell group did many activities outside of the classroom. The detail of the cell group activities for each skill is as follows:

\section{Listening}

The are many ways to do for cell groups for listening: (1) Each member was assigned to practice listening in self access learning laboratory. The laboratory provided the material for listening and could be accessed anytime at the working hours; (2) After listening to the audio, each cell group had to discuss the answer and got the explanation of the answer; (3) If all members did not know the answer, nor had no idea about it, they could ask that question in BINUS MAYA FORUM, so other groups, either in the same class or other classes parallel could give the answer and discuss about it; (4) Every week, the leader had to make a short report about their activities in the report form provided.

\section{Reading}

1. Each member of the groups had to read the material in the printed material from text book.

2. Then they had to meet in cell group to discuss about reading texts, including new vocabularies, the main idea and the answer of the questions.

3. They were asked to write problems they face during the discussion such as if all members do not know the correct answer or if they do not know the idea of the reading texts.

4. They have to write the problems in BINUSMAYA FORUM and ask other groups to share ideas and discuss the answer together.

\section{Evaluation}

To control the cell group activities outside the classroom, each cell has to make a report in weekly based. They had to write in detail about the activity they learn. The report consisted of the time of activities, the activities they did and the problem they faced. From the report, the lecture could discuss in the classroom and find the solution about the problems. The example of the report can be seen in appendix 1. English Entrant evaluation carried out in three ways:

\section{Listening Score}

Binus set different score for each level of English although the target achievement is the same. For listening the highest score is 30. It means that when the students reach the score there is no mistakes on their test. For English Entrant, the lowest level of Binus General English, score 12 is categorized into B level from A, B, C, D and E where A is the highest score and E is failed.

\section{Reading} minimum 12.

Reading section has the same level as the listening one. The level required to get B level is 


\section{Group activities}

Based on the weekly report the students made here is the result



R 1-3 means that the group did reading cell group activities for one till three times during the semester. It shows 7 groups (group 2, 3, 5, 6, 8, 10, 12) while R $4-6$ shows that only 5 other groups did reading cell group for $4-6$ times during a semester.

L 1-3 on the other side shows that there are nine groups did listening cell group activities and only three groups did the listening activities for 4 till 6 times.

\section{Students Achievement}

Student achievement is discussed into two different skills

\section{Reading Achievement}

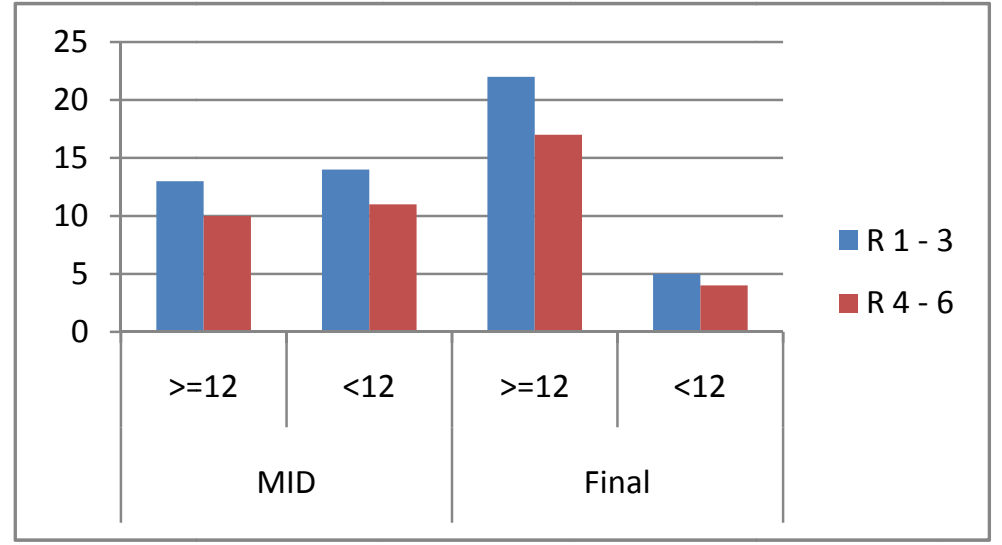

The chart shows that the students who achieved less than 12 in R1-3 in mid test are higher than the ones who had the reading cell group activities $4-6$ time during the semester. While in Final examination the result shows that the students who achieved more than 12 are getting bigger comparing to the ones which achieved less than 12 . 


\section{Listening Achievement}

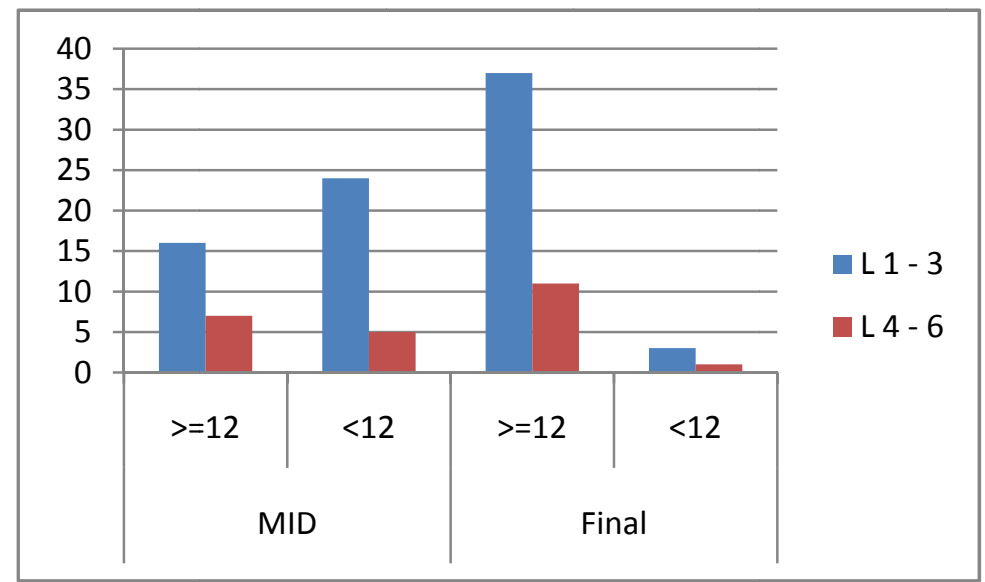

The chart shows that there is a strong tendency that the students score for listening score from mid test to the test tends to reach higher than 12, either from the activities of L1 - 3 or L 4-6

\section{All Components of Achievement}

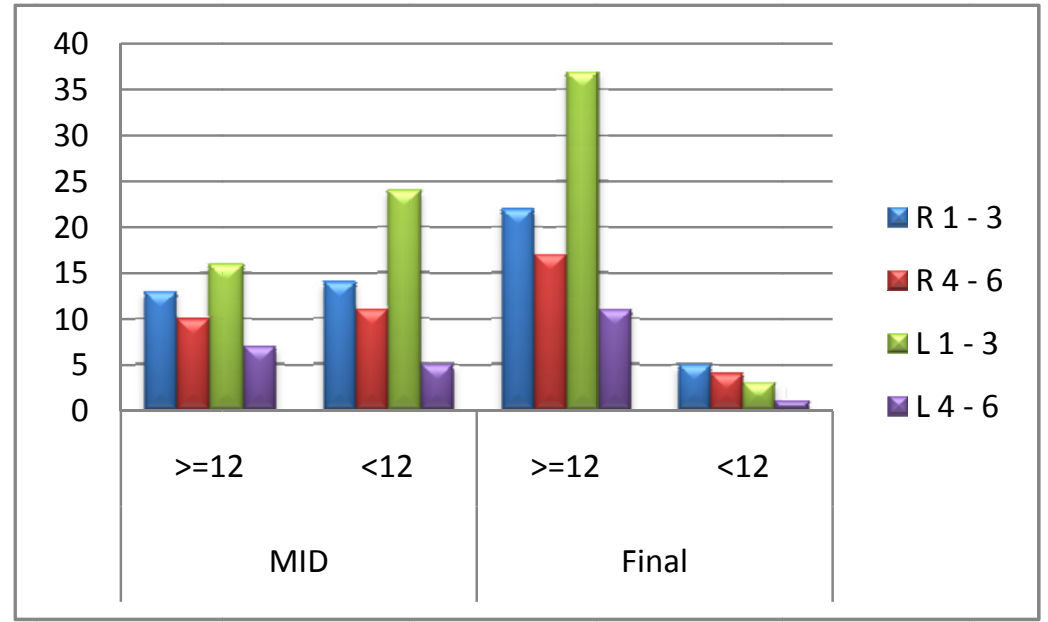

The chart shows that there is a higher achievement of most students from the mid test to the final one. Listening achievement of L1-3 from 16 students who achieved more than 12, reached more than 35 students who achieved more than 12. Listening score for those who achieved less then 12 were 24 students; while in final exam is only 4 students. In reading score achievement remained the same. 


\section{CONCLUSION}

From the discussion, it can be concluded the cell group method is used by some lecturers at BINUS University to teach English Entrant classes since it offers a method which supports a lecture to do class management easier, especially the students attendance and also supports a lecturer to note the students progress. The most important thing of a cell group method in which students were given opportunity to develop themselves in group, was that they could reach the better score. Therefore, cell group system has the good impact for the students to achieve better score. The result also shows that the cell group independent activities support the achievement of students score in listening and reading. Students who did the independent cell group activities for 3-6 times in a semester got the higher score comparing to those who did only $1-3$ times either in reading and listening. It can be said that the more the students did the cell group independent activities, the better score they got. Therefore, the independent cell group method positively influences the students' score achievement especially in reading and listening skills. It is strongly suggested for lecturers who teach big classes to use this method or to modify it to meet the need of the students.

\section{REFERENCES}

Ives, Sallie M. A Survival Handbook for Teaching Large Classes. Available at http://teaching.uncc.edu/resources/best-practice-articles/large-classes/handbook-large-classes last views 7 April 2011

Binusmaya available at http://newbinusmaya.binus.ac.id/ last viewed April 5, 2011

Brown, Douglas. 2001. Teaching by Principles. An Interactive approach to Language Pedagogy. Second Edition. New York: Addison Wesley Longman, Inc. ISBN: 0-13-028283-9

Harmer, Jeremi. 2001. The Practice of English Language Teaching. Essex: Pearson Education Limited. ISBN: 0582403855

Richard and Renandya (Ed). 2002. Method in Language Teaching. An Anthology of Current Practice. New York: Cambrige Universiry press. ISBN: 13 978-0-521-80829 


\section{Appendices}

Appendix 1: Weekly Report Form

\begin{tabular}{|c|c|c|c|c|}
\hline Class: 01PHJ & Group: 01 & Leader: & $\begin{array}{r}\text { Member: } 1 \text {. } \\
2 .\end{array}$ & $\begin{array}{l}2 . \\
4 .\end{array}$ \\
\hline Day/date & Time & Activities/ description & Participants & Notes \\
\hline $\begin{array}{l}\text { Tuesday } \\
12 \text { October } 2010 \\
\text { Wednesday } \\
13 \text { Oct } 2010\end{array}$ & $\begin{array}{l}11.00- \\
11.00 \\
\\
14.00- \\
15.00\end{array}$ & $\begin{array}{l}\text { Listening (730) } \\
\text { Listen to IBT listening mini test } 1 \\
\text { Speaking } \\
\text { Making dialogues and practicing about } \\
\text { telephoning. } 1 \text { dialogue for } 2 \text { members } \\
\text { and 1dialogue for } 3 \text { members }\end{array}$ & $\begin{array}{l}\text { All } \\
\text { All }\end{array}$ & $\begin{array}{l}\text { Difficulties in } \\
\text { catching the ideas. } \\
\text { No }\end{array}$ \\
\hline Leader's Signature & \multicolumn{4}{|c|}{ Lecture’s Signature } \\
\hline Name & & \multicolumn{3}{|c|}{ Name } \\
\hline
\end{tabular}

Appendix 2: list of students, score and number of cell group activities

\begin{tabular}{|c|c|c|c|c|c|c|c|c|c|}
\hline no & StudentNumber & Name & group & skills & $\begin{array}{c}\text { Number } \\
\text { of } \\
\text { activities }\end{array}$ & R-mid & R-Final & L-Mid & L-Final \\
\hline 1 & 1401087132 & FUAAD RAMADHAN ACHMAD & 1 & $R$ & 4 & 18 & 17 & 13 & 16 \\
\hline 2 & 1501143512 & LIUS YULIADI & & $\mathrm{L}$ & 5 & 13 & 13 & 15 & 9 \\
\hline 3 & 1501144143 & AKMAL ILYASA & & W & 4 & 5 & 12 & 6 & 19 \\
\hline 4 & 1501147864 & SHARON MONICA & & $S$ & 1 & 13 & 15 & 17 & 18 \\
\hline 5 & 1501152473 & VINSON HALIM & 2 & $\mathrm{R}$ & 2 & 10 & 22 & 15 & 19 \\
\hline 6 & 1501153103 & GLAYTON YAN & & L & 3 & 16 & 16 & 15 & 22 \\
\hline 7 & 1501153684 & STEVEN IMMANUEL & & w & 3 & 13 & 17 & 10 & 14 \\
\hline 8 & 1501157713 & ALFREDO TJIPTO SETIAWAN & & S & 2 & 10 & 10 & 14 & 15 \\
\hline 9 & 1501161383 & TAUFIK WIDYANTO & & & & 9 & 12 & 12 & 16 \\
\hline 10 & 1501161982 & PRISKHA PERMATA SARI & 3 & $\mathrm{R}$ & 3 & 8 & 10 & 16 & 10 \\
\hline 11 & 1501162783 & JENNIFER KRISTIANI ADAM & & L & 4 & 18 & 20 & 11 & 19 \\
\hline 12 & 1501162972 & CHRIS TOPHER ALFONS & & w & 2 & 22 & 26 & 18 & 25 \\
\hline 14 & 1501163470 & ASTRINI & & $S$ & 3 & 10 & 10 & 10 & 18 \\
\hline 15 & 1501163520 & DEA OKTAVIA & 4 & $\mathrm{R}$ & 4 & 19 & 19 & 5 & 17 \\
\hline 16 & 1501163874 & ERIKA DIAN KARTIKA & & L & 1 & 6 & 7 & 10 & 15 \\
\hline 17 & 1501163893 & HAMDAN LUKMANA & & W & 4 & 15 & 13 & 7 & 23 \\
\hline 18 & 1501164031 & HARUKI AL BAKIR & & $S$ & 1 & 6 & 19 & 14 & 17 \\
\hline 19 & 1501165311 & IQBAL AKBAR BACHTIAR & & & & 10 & 18 & 10 & 18 \\
\hline
\end{tabular}




\begin{tabular}{|c|c|c|c|c|c|c|c|c|c|}
\hline no & StudentNumber & Name & group & skills & $\begin{array}{c}\text { Number } \\
\text { of } \\
\text { activities }\end{array}$ & R-mid & R-Final & L-Mid & L-Final \\
\hline 20 & 1501165942 & LEO ARDI & 5 & $\mathrm{R}$ & 1 & 10 & 19 & 17 & 21 \\
\hline 21 & 1501166705 & GERRY WAHYU DEWATARA & & $\mathrm{L}$ & 4 & 20 & 30 & 20 & 24 \\
\hline 22 & 1501166775 & ANDRE ANGGARA & & W & 1 & 13 & 15 & 15 & 15 \\
\hline 23 & 1501167020 & HADRIAN KRISTANTO & & $\mathrm{S}$ & 3 & 18 & 8 & 16 & 16 \\
\hline 24 & 1501167235 & AMELIA CHOERUNISA & 6 & $\mathrm{R}$ & 2 & 16 & 18 & 5 & 9 \\
\hline 25 & 1501167475 & ACHMAD AUZAN ZULKARAMI & & L & 2 & 4 & 12 & 5 & 13 \\
\hline 26 & 1501167941 & TIRTA DANESWARA NOOR & & W & 3 & 16 & 26 & 16 & 16 \\
\hline 27 & 1501168553 & DWI PUTRI RAMADINI & & $\mathrm{S}$ & 1 & 11 & 15 & 10 & 12 \\
\hline 28 & 1501169070 & KRISJIANA BAHARUDIN & 7 & $\mathrm{R}$ & 5 & 17 & 9 & 21 & 17 \\
\hline 29 & 1501184222 & CHANDRA MUSTADIANSYAH & & L & 3 & 9 & 24 & 9 & 24 \\
\hline 30 & 1501184374 & $\begin{array}{l}\text { R RIZKHIE ARISSAPUTRA } \\
\text { TJAHJONO }\end{array}$ & & W & 2 & 5 & 26 & 8 & 24 \\
\hline 31 & 1501184866 & $\begin{array}{l}\text { NIMAS WIDYAWATI } \\
\text { NINGRUM }\end{array}$ & & $S$ & 3 & 3 & 9 & 7 & 13 \\
\hline 32 & 1501196645 & KEVIN NUGRAHA & 8 & $\mathrm{R}$ & 2 & 9 & 15 & 12 & 8 \\
\hline 33 & 1501199930 & RICKY FALAH & & L & 2 & 12 & 22 & 12 & 25 \\
\hline 34 & 1501199994 & DANNY WAHONO & & W & 4 & 19 & 23 & 22 & 25 \\
\hline 35 & 1501200106 & RILI SEPTIEFANERA & & $S$ & 0 & 20 & 22 & 14 & 19 \\
\hline 36 & 1501200163 & VIVIN ARINI & & & & 7 & 11 & 5 & 14 \\
\hline 37 & 1501200301 & INTAN SORAYA & 9 & $\mathrm{R}$ & 7 & 8 & 22 & 7 & 24 \\
\hline 38 & 1501200926 & ADRIAN PRATAMA AFRIANTO & & $\mathrm{L}$ & 4 & 14 & 19 & 18 & 16 \\
\hline 39 & 1501201033 & ADINE NUR RACHMA & & W & 2 & 13 & 24 & 9 & 25 \\
\hline 40 & 1501201203 & DIMAS FATTAH ANDICAHYO & & $\mathrm{S}$ & 1 & 15 & 23 & 11 & 15 \\
\hline 41 & 1501201336 & CINDY ARIANDI VITTADINI & 10 & $\mathrm{R}$ & 3 & 17 & 26 & 9 & 22 \\
\hline 42 & 1501201355 & FIKRI SAMSU RIZAL & & $\mathrm{L}$ & 2 & 11 & 16 & 9 & 19 \\
\hline 43 & 1501201494 & FAHMI SULAKSONO & & W & 2 & 11 & 15 & 10 & 21 \\
\hline 44 & 1501201550 & IRSALINA AMALIA AWANIS & & $S$ & 3 & 10 & 13 & 7 & 13 \\
\hline 45 & 1501203013 & FAUZANTINO & & & & 3 & 24 & 3 & 25 \\
\hline 46 & 1501203165 & BERBUDI SATYA LEKSONO & 11 & $\mathrm{R}$ & 5 & 6 & 23 & 7 & 24 \\
\hline 47 & 1501203511 & BESLINA SARAS MAHARANI & & $\mathrm{L}$ & 2 & 13 & 14 & 13 & 20 \\
\hline 48 & 1501203581 & SYIFA MUTHMAINNAH & & W & 2 & 11 & 14 & 12 & 16 \\
\hline 49 & 1501203966 & ERIK YEHEZKIEL & & $\mathrm{S}$ & 1 & 4 & 9 & 11 & 10 \\
\hline 50 & 1501204470 & NORMA FEBRIANI & 12 & $\mathrm{R}$ & 2 & 11 & 18 & 4 & 15 \\
\hline 51 & 1501204703 & HAIKAL ALIF & & $\mathrm{L}$ & 3 & 13 & 14 & 11 & 21 \\
\hline 52 & 1501204760 & PETER ANDRIAN & & W & 1 & 18 & 12 & 8 & 14 \\
\hline 53 & 1501205920 & DESFIN NADHIRIAWAN & & $S$ & 1 & 11 & 20 & 8 & 23 \\
\hline
\end{tabular}

